\title{
Progresivní multifokální leukoencefalopatie - editorial
}

\author{
Pavel Polák \\ Oddělení klinické hematologie FN Brno \\ Komentář k | Editorial on \\ Sokol J et al. Rituximab-associated progressive multifocal leukoencephalopathy. \\ Vnitř Lék 2017; 63(1): 60-64.
}

Progresivní multifokální leukoencefalopatie (PML) patří stále $\mathrm{k}$ velmi vzácným onemocněním. Virus byl poprvé prokázán v roce 1971 u pacienta s chronickou lymfatickou leukemií [1]. V 90. letech 20. století byl zaznamenán epidemický výskyt PML u pacientů infikovaných lidským virem imunitní nedostatečnosti (human immunodeficiency virus - HIV), a proto PML patří mezi tzv. onemocnění indikativní pro AIDS [2]. $V$ rámci diferenciální diagnostiky PML je tedy vždy nezbytné nákazu HIV vyloučit. S vývojem transplantační medicíny a imunosupresivní a imunomodulační terapie se spektrum pacientů ohrožených PML výrazně rozšiřuje - incidenci PML v těchto jednotlivých skupinách uvádí tab. Z tohoto důvodu představuje př́pad prezentovaný slovenskými kolegy s největší pravděpodobností spíše pověstnou špičku ledovce.

Samotný původce PML, označovaný jako JC virus (iniciály pacienta Johna Cunninghama, od nějž byl virus poprvé izolován), patři do čeledi polyomavirů (v literatuře Ize rovněž nalézt zkratku JCpyV odpovídající JC-polyomaviru). Jedná se o neobalený virus, jehož genetická informace je nesena dvouvláknovou deoxyribonukleovou kyselinou (deoxyribonucleic acid - DNA). Z epidemiologických studií vyplývá vysoká promořenost populace celosvětově (dosahující až 60-70\%), patogenita viru je však nízká - jedná se tedy o velmi úspěšný patogen [2]. Primoinfekce nastává po vstupu viru do makroorganizmu v oblasti orofaryngu a není doprovázena specifickými př́znaky. Část nakažených jedinců vylučuje virus močí i několik týdnů a stává se tak asymptomatickým zdrojem nákazy, která nemusí být nutně doprovázena sérokonverzí. Následuje fáze tzv. virové latence, během níž virus přetrvává v buňkách kostní dřeně či sekundárních lymfatických orgánů a jeho replikační aktivita je nulová či velmi nízká. Při poruše imunitních regulací (pokles počtu CD4 ${ }^{+} / \mathrm{CD}^{+}$T-lymfocytů, biologická terapie apod) dochází k dynamické replikaci viru a k jeho diseminaci. Způsob přestupu viru do tkání centrální nervové soustavy (CNS) není jednoznačně objasněn, spekuluje se o prímém průniku viru nebo o jeho transportu přes hematoencefalickou bariéru infikova- nými lymfocyty, monocyty nebo endoteliemi. V CNS jeví virus zvláštní afinitu k astrocytům a oligodendrocytům, v nichž nastává tzv. lytická replikační fáze doprovázená balonovou degenerací a následně i lýzou postižených buněk. Replikace viru je pomalá a trvá rádově týdny. Tyto základní patofyziologické mechanizmy rozvoje PML vysvětlují, proč je vývoj klinického stavu zpravidla postupný (subklinický). $V$ této době Ize i u těžce imunokompromitovaných prokázat výrazný vzestup titru protilátek anti-JCV v séru i v likvoru (je pozitivní index intratekální syntézy); naopak virus nemusí být nutně průkazný $v$ moči (pomocí polymerázové řetězové reakce/polymerase chain reaction - PCR, detekční limity současných metod jsou 10 kopií viru/ml). Bylo prokázáno, že absolutní počet kopií viru v moči nekoreluje $s$ výší titru protilátek $v$ séru a dále že nepřítomnost viru v moči zcela nevylučuje možnost rozvoje PML. Diagnostiku dále znesnadňuje možnost prítomnosti JCV-DNA v likvoru i u jedinců bez klinických či radiologických známek PML. Samotný virus vykazuje vysokou mutační aktivitu a perzistuje intracelulárně, proto nedochází k jeho absolutní neutralizaci a eradikaci již vytvořenými protilátkami $[3-6,9,10]$.

Mezi rizikové faktory pro rozvoj PML patří pozitivita protilátek proti JCV v séru, předchozí imunosupresivní terapie a délka léčby natalizumabem [4]. Pro samotný rozvoj onemocnění musí být splněno několik podmínek: - porucha imunitního systému hostitele (nejvýznamnější faktor)

\begin{tabular}{|c|c|}
\hline základní onemocnění & incidence \\
\hline HIV/AIDS & $1: 100$ \\
\hline po orgánové transplantaci & $1: 1000000$ \\
\hline $\begin{array}{l}\text { roztroušená skleróza mozko- } \\
\text { míšní léčená natalizumabem }\end{array}$ & $\begin{array}{l}1: 300 \text { (resp. } 1: 80 \text { při aplikaci } \\
\text { více než } 24 \text { dávek natalizumabu) }\end{array}$ \\
\hline $\begin{array}{l}\text { hematoonkologické } \\
\text { onemocnění }\end{array}$ & $1-5 / 100000$ \\
\hline
\end{tabular}


- mutační aktivita viru se zvýšenou replikací v B-lymfocytech a postižených gliových buňkách

- prítomnost viru v CNS

- zvýšená koncentrace tzv. DNA vázajících faktorů [2]

Podezření na PML by mělo být vždy vyjádřeno u imunokompromitovaného pacienta $s$ atypickým klinickým neurologickým nálezem a s multifokálními lézemi CNS zjištěnými pomocí magnetické rezonance. A naopak u všech pacientů s multifokálními lézemi CNS a s atypickým klinickým neurologickým nálezem musí být vyloučen těžký imunodeficit včetně onemocnění HIV/AIDS.

Kauzální léčba této infekce není známa. U pacientů léčených natalizumabem (a pravděpodobně i u pacientů léčených efalizumabem) Ize provést výměnné plazmaferézy (5 cyklů). Naopak u pacientů léčených rituximabem nemá pro krátký biologický poločas léčiva plazmaferéza prakticky žádný význam. Během plazmaferézy dochází však i ke clearance protilátek anti-JCV a další sérologické testy mohou být falešně negativní $[4,7]$. Oproti tomu je po nitrožilní aplikaci imunoglobulinů (IVIG) možná falešná pozitivita protilátek anti-JCV. Postupem času od aplikace IVIG dochází k poklesu titru těchto protilátek a je možná i séroreverze do jejich neprůkaznosti. Vyšetření protilátek anti-JCV by tedy nemělo být provedeno dříve než 30 dnů po aplikaci IVIG. Vliv ostatních krevních derivátů a prípravků na hladiny protilátek anti-JCV není plně vyloučen, a proto by mělo být sérologické vyšetření prováděno opakovaně se zohledněním uvedené léčby a klinického stavu [8].

Pravidelnou a velmi závažnou komplikací léčby PML (zvláště po plazmaferéze) je rozvoj imunorestitučního zánětlivého syndromu (immune restoration inflammatory syndrome - IRIS). Tento stav nastává při obnovení imunitních funkcí s následnou excesivní zánětlivou aktivitou destruktivně pưsobící na tkáně, ve kterých IRIS probíhá. $\checkmark$ prípadě $P M L$ dochází po jisté době stabilizace klinického stavu k další prudké deterioraci s možným fatálním vyústěním [4].

Prognóza onemocnění je velmi vážná, přibližně $20 \%$ nemocných umírá na PML a na přidružené (zpravidla infekční) komplikace.

Přestože několik př́padů PML bylo popsáno i v českém písemnictví, je toto onemocnění natolik vzácné, že jeho diagnostika klade extrémní nároky na ošetřující lékaře různých odborností (i s ohledem na dlouhou fázi preklinického rozvoje PML) [11-14]. Je tedy obdivuhodné, že se navzdory veškerým nesnázím podařilo slovenským kolegům případ diagnosticky uzavřít a že nám jej nabízejí k poučení.

\section{Literatura}

1. Padgett BL, Walker DL, ZuRhein GM et al. Cultivation of papova-like virus from human brain with progressive multifocal leucoencephalopathy. Lancet 1971; 1(7712): 1257-1260.

2. Ferenczy MW, Marshall LJ, Nelson ChDS et al. Molecular biology, epidemiology, and pathogenesis of progressive multifocal leukoencephalopathy, the JC virus-induced demyelinating disease of the human brain. Clin Microbiol Rev 2012; 25(3): 471-506. Dostupné z DOI: <http:// dx.doi.org/10.1128/CMR.05031-11>.

3. Monaco MC, Major EO. Immune system involvement in the pathogenesis of JC virus induced PML: what is learned from studies of patients with underlying diseases and therapies as risk factors. Front Immunol 2015; 6:159. Dostupné z DOI: <http://dx.doi.org/10.3389/ fimmu.2015.00159>.

4. Kornek B. An update on the use of natalizumab in the treatment of multiple sclerosis: appropriate patient selection and special considerations. Patient Prefer Adherence 2015; 9: 675-684. Dostupné z DOI: $<$ http://dx.doi.org/10.2147/PPA.S20791>.

5. Berger JR, Sidney MD, Houff MD et al. JC virus antibody status underestimates infection rates. Ann Neurol 2013; 74(1): 84-90. Dostupné z DOI: <http://dx.doi.org/10.1002/ana.23893>.

6. Nakamichi K, Mizusawa H, Yamada M et al. Characteristics of progressive multifocal leukoencephalopathy clarified through internet-assisted laboratory surveillance in Japan. BMC Neurol 2012; 12: 121. Dostupné z DOI: <http://dx.doi.org/10.1186/1471-2377-12-121>.

7. Fox R Advances in the management of PML: focus on natalizumab. Cleve Clin J Med 2011; 78(Suppl 2): S33-S37. Dostupné z DOI: <http:// dx.doi.org/10.3949/ccjm.78.s2.08>.

8. Kister I, Kuesters G, Chamot E et al. IV immunoglobulin confounds JC virus antibody serostatus determination. Neurol Neuroimmunol Neuroinflammation 2014; 1(3): e29. Dostupné z DOI: <http://dx.doi. org/10.1212/NXI.0000000000000029>.

9. Bozic C, Subramanyam M, Richman $S$ et al. Anti-JC virus (JCV) antibody prevalence in the JCV epidemiology in MS (JEMS) trial. Eur J Neurol 2014; 21(2): 299-304. Dostupné z DOI: <http://dx.doi. org/10.1111/ene.12304>.

10. Rossi F, Newsome SD, Viscidi R Molecular diagnostic tests to predict the risk of progressive multifocal leukoencephalopathy in natalizumab-treated multiple sclerosis patients. Mol Cell Probes 2015; 29(1): 54-62. Dostupné z DOI: <http://dx.doi.org/10.1016/j.mcp.2014.11.007>.

11. Štětkářová I, Medová E, Bučilová V et al. Progresivní multifokální leukoencefalopatie u nemocné s roztroušenou sklerózou léčenou natalizumabem. Čes Radiol 2013; 67(1): 35-38.

12. Vališ M, Belada D, Taláb R et al. Progresivní multifokální leukoencefalopatie jako komplikace léčby lymfomu - kazuistika. Česk Slov Neurol N 2009; 72/105(2): 159-161.

13. Táborský $P$, Hrabánek J, Jirásek $A$ et al. Progresivní multifokální leukoencefalopatie u nemocné po transplantaci ledviny. Vnitř Lék 1998; 44(2): 108-110.

14. Horáková D, Havrdová E. Protilátky proti JC viru a stratifikace rizika progresivní multifokální leukoencefalopatie u pacientů s roztroušenou sklerózou. Doporučení k použití nového testu STRATIFY JCVTM. Neurol praxi 2011; 12(5): 364-365.

\section{MUDr. Pavel Polák, Ph.D. $\triangle$ pavel.polak@fnbrno.cz}

Oddělení klinické hematologie FN Brno www.fnbrno.cz

Doručeno do redakce 21. 3. 2016 